\title{
Methods of Segmentation and Positioning in the Product Market with Access to a New Foreign Market
}

\author{
Ph.D. Candidate Rana Mikailova (UNEC- Azerbaijan State University of Economics, \\ Azerbaijan)
}

\begin{abstract}
Entering a new foreign market has always remained an urgent problem. The interrelation of the internal and external commodity market is an important condition for the successful development of the economy of any country. Foreign experience shows that various strategic approaches are used for this purpose. The basic basis of the strategic approach is the systematic coverage of the product market, which includes undifferentiated marketing, differentiated marketing and concentrated marketing. Below we will consider in more detail the above strategic approaches to coverage of the product market. In particular, it is considered when an enterprise refuses features and explores the entire market from the position of a single approach. Differentiated marketing tactics are not about identifying a single need, but a general one. These include the formation of a product and a marketing program that will be useful to a significant number of consumers. A distinctive feature of differentiated marketing is that the company operates in a number of market segments and forms a distinctive offer for them. This approach is based on offering different products to the market in order to increase sales and penetrate deeper into the development of product market segments. Finally, concentrated marketing provides an opportunity for businesses to discover an additional opportunity that is more attractive from a resource constraint perspective. It is manifested by the concentration of efforts on a small share of a large commodity market.
\end{abstract}

\section{Introduction}

Marketing research methods make it possible to study in more detail the issues of segmentation in the product market. First of all, let us define the category of segmentation, which, in our opinion, is the differentiation of the product market into groups of consumers that have relatively similar content for a deeper study of their maneuverability in choosing target segments of the product market.

At the same time, the segmentation of the commodity market is determined by the grouping of buyers in the consumer market into various subsystems, within which buyers have approximately equal demands, which are satisfied by an integrated marketing system. There are no standard methods for segmenting the market. The researcher of the commodity market should choose different variants of segmentation based on variable parameters, one or several at once, in order to develop a more rational study of the market structure.

\section{Methodology}

Along with the segmentation of the product market in marketing research, an important role is assigned to the issues of positioning, which is a set of measures that contribute to the formation of individual opinions among buyers about certain products. The components of product positioning on the market are:

- selection of the positioning component, taking into account the usefulness of the product for the buyer, which is the reason for purchasing it in a particular enterprise;

- positioning takes place for the selected target segment, because for individual sites the most significant components of positioning will naturally be individual (Velichko V.V., 2018);

- positioning involves the approach of an adversary who is displaying goods for a given target segment

Positioning principles should also be defined, which can be categorized into the following system:

- phasing of the chosen position, functioning without changes for a relatively long period. At the same time, a number of position components may change, but not the position itself as a whole;

- information availability of the position of the enterprise in relation to the consumer, its simplicity and availability;

- the components of the trade should consistently and realistically reflect the chosen position of the firm.

Marketing research on product positioning contributes to the determination of the key advantage of the product, which in practice is called the positioning attribute.

Selecting clients for positioning begins with identifying segment potential and benefits. Metrics are grouped according to the interests that they hope to get from the product. 


\begin{tabular}{|l|l|}
\hline Groups & Classification of approaches \\
\hline Zones & Territorial approach \\
\hline Regions & Major world economic zones \\
\hline Cities & $\begin{array}{l}\text { With a population from 5 thousand people to more than 1 } \\
\text { million people }\end{array}$ \\
\hline Population density & Cities, towns, countryside \\
\hline \multicolumn{1}{|c|}{ Social approach } \\
\hline Social level & $(-) ;(-;+) ;(+)$ \\
\hline Life style & Traditional, luxurious \\
\hline \multicolumn{2}{|c|}{ Behavioral approach } \\
\hline Making a purchase & A special case \\
\hline Seeking benefits & Quality, service, economy \\
\hline Intensity of purchases & Low, moderate and active buyers \\
\hline Directional level & Medium, strong, absolute \\
\hline Consumer readiness level for product perception & Informed, interested \\
\hline Product attitude & Positive, negative \\
\hline
\end{tabular}

Table 1. Selection of Variables Used to Segment the Product Market.

\section{Results}

Quality-based positioning marketing research is generating increased interest from product use. The buyer gets the impression that past experience on the price they paid is critical. The product is rated very worthwhile if it exceeds such expectations. The challenge is that every positive experience creates an expectation of better quality in the long run.

Marketing research of product positioning on the market consists of a number of successive phases:

a) identify a set of competitive products serving the target market;

b) compose a set of defining elements covering the product market in which the positions are distributed;

c) collection of information, study a sample of consumers and potential buyers of the perception of a particular product by the relevant attributes;

d) identify the condition of the goods on the commodity market;

e) identify a relatively preferred set of defining attributes for customers;

f) investigate the correspondence between the preferences of market segments and the present position of the product;

j) draw conclusions about positioning and develop proposals for the further formation of a marketing strategy.

It should be noted that the use of segmentation and positioning methods in the domestic product market contributes to a successful entry into a new foreign market.

Marketing research of product market segmentation and product positioning make it possible to decide on entering the foreign market.

The phases of the methodology for selecting a foreign market and modeling the economic indicators of exports are built as follows:

A. Assessment of the capacity of the commodity market, within the boundaries of which the organization of the sale of goods is supposed.

B. Diagnostics of the structure of the target product market.

C. Assessment of barriers to entry and exit within product markets.

The capacity of the consumer market, as noted, is the volume of sales of a certain product in a given market of the country during a certain period of time. Many marketers, when characterizing the market capacity, are guided by its potential level and define it as "the potential volume of sales of goods on the market."

Assessment of the dynamics of market capacity as a whole and of individual types of goods is the main one for diagnosing one's capabilities in the product market, developing a strategy and marketing policy. World experience shows that firms should have monthly data on the capacity of the consumer market and the share of firms in it, which makes it possible to quickly respond to changes in the commodity market. However, there is no uniform approach to such studies. When calculating the capacity of the commodity market as an economic category, two approaches should be noted: assessment of the satisfied demand; assessment of potential demand.

For non-food products, the potential capacity can be calculated by the capacity used by firms. In a word, the potential market capacity should be understood in the future as a situation when all commodity producers will fully utilize their production capacities.

It is also necessary to diagnose the production of goods within the regional boundaries of the market. 
Market diagnostics is not limited to the proposed ways and can be supplemented by a study of market demand, price data, an assessment of the balance of supply and demand in the market. The result of marketing research: identification of promising directions for selling goods.

The main factors in diagnosing the market structure are indicators of market concentration, which is discussed in detail in the previous sections of the work.

Further, in order to make a rational decision by firms to export goods to the foreign market, it is proposed to consider the barriers to doing business in these countries

As noted earlier, market segmentation is expressed as an activity to classify potential buyers, goods produced and sold by the firm in accordance with the qualitative specifics of demand. In addition, market segmentation is possible based on criteria not related to indicators. Segmentation by product type is a way of dividing the market by functional and ICT components of the product manufacturers.

The next step is the process of modeling the indicators of the export of goods. The essence of modeling comes down to comparing the options for the volume of admission and the price of goods, as well as prices and tariffs for energy resources. The ratio of these parameters is considered rational, which will allow achieving the highest income of the export product.

At the beginning of the simulation, the main parameters for the export product are set: the volume of output and the corresponding costs (Virina M.E., 2017).

Taking into account the relationship of income with costs and results, commercial and economic calculations make it possible to determine the influence of decisions made on changes in volumes, prices and material costs on the income of a given product.

The modeling of export indicators for a product should be the result of export assessments of the real situation by the personnel of the marketing department, economists and financiers of the exporting firms.

Let us consider the practical side of this methodology using the example of export-import operations in the Republic of Azerbaijan.

Diagnostics of the market environment for foreign trade will be carried out by calculating the real capacity of the market for export and import goods in the republic. For this, we will use data on exports "Table 1", imports "Table 2". and the volume of production of industrial and food products.

\begin{tabular}{|c|c|c|c|c|c|c|c|c|c|c|}
\hline & \multicolumn{10}{|c|}{ Export, mln USD } \\
\hline & 2013 & $\%$ & 2014 & $\%$ & 2015 & $\%$ & 2016 & $\%$ & 2017 & $\%$ \\
\hline Total & 23975,1 & 100 & 21828,6 & 100 & 12729,1 & 100 & 15457,1 & 100 & 13811,6 & 100 \\
\hline Food products & 647,8 & 2,7 & 648,2 & 3,0 & 625,1 & 4,9 & 478,2 & 3,6 & 601,4 & 4,4 \\
\hline $\begin{array}{l}\text { Drinks and } \\
\text { tobacco }\end{array}$ & 41,7 & 0,2 & 44,6 & 0,2 & 35,2 & 0,3 & 37,6 & 0,2 & 37,2 & 0,3 \\
\hline $\begin{array}{l}\text { Unproductive } \\
\text { resources }\end{array}$ & 47,0 & 0,2 & 33,9 & 0,2 & 25,7 & 0,2 & 45,2 & 0,3 & 79,0 & 0,6 \\
\hline Mineral fuel & 22229,8 & 92,7 & 30177,2 & 92,4 & 11187,1 & 87,9 & 12270,1 & 91,2 & 12358,7 & 89,5 \\
\hline $\begin{array}{l}\text { Chemical } \\
\text { goods }\end{array}$ & 175,4 & 0,7 & 231,1 & 1,1 & 190,2 & 1,5 & 159,2 & 1,1 & 178,7 & 1,3 \\
\hline $\begin{array}{l}\text { Prom. } \\
\text { products }\end{array}$ & 265,0 & 1,1 & 200,9 & 0,9 & 179,8 & 1,4 & 273,7 & 2,0 & 323,4 & 2,3 \\
\hline $\begin{array}{l}\text { Cars and } \\
\text { transport }\end{array}$ & 149,3 & 0,6 & 190,1 & 0,9 & 88,9 & 0,7 & 15,7 & 0,1 & 19,3 & 0,1 \\
\hline Others & 72,9 & 0,3 & 76,9 & 0,3 & 82,8 & 0,7 & 76,8 & 0,6 & 139,4 & 1,0 \\
\hline
\end{tabular}

Table 2. Diagnostics and Analysis of the Structure of Export of Goods of the Republic of Azerbaijan

Analysis of import flows in trade shows that such commodity groups as mineral fuels (89.5\%); food products (4.4\%); chemical products $(1.3 \%)$, and the rest of the goods make up a negligible share, i.e. less than $1 \%$.

Export dynamics show that there is a positive trend for certain goods. For example, for 2013-2017. for food products, the share of exports increased from $2.7 \%$ to $4.4 \%$, for industrial goods - from $11 \%$ to $2.3 \%$. However, the dominant position is still occupied by energy resources. Their share decreased from $92.7 \%$ to $89.5 \%$ ( Zagidulina G.M., 2015).

At the same time, the diagnostics and analysis of imports shows that foreign goods are actively imported in the republic. For food products for 2013-2017 their share increased from $9.9 \%$ to $14.36 \%$, mineral fuels - from $1.3 \%$ to $4.3 \%$, chemical products - from $8.7 \%$ to $11.8 \%$, finished products - from $8.7 \%$ up to $9.8 \%$. 


\begin{tabular}{|c|c|c|c|c|c|c|c|c|c|c|}
\hline & \multicolumn{10}{|c|}{ Imports, mln USD } \\
\hline & 2013 & $\%$ & 2014 & $\%$ & 2015 & $\%$ & 2016 & $\%$ & 2017 & $\%$ \\
\hline Total & 10712,5 & 100 & 9187,7 & 100 & 9216,7 & 100 & 8489,1 & 100 & 8782,0 & 100 \\
\hline Food products & 1062,0 & 9,9 & 982,3 & 10,7 & 910,5 & 9,9 & 1189,7 & 14,0 & 1232,4 & 14,6 \\
\hline $\begin{array}{l}\text { Drinks and } \\
\text { tobacco }\end{array}$ & 400,2 & 3,7 & 469,3 & 5,1 & 360,0 & 3,9 & 210,0 & 2,5 & 231,8 & 2,6 \\
\hline $\begin{array}{l}\text { Unproductive } \\
\text { resources }\end{array}$ & 324,0 & 3,0 & 146,3 & 1,6 & 212,0 & 2,30 & 187,4 & 2,2 & 231,1 & 2,6 \\
\hline Mineral fuel & 141,6 & 1,3 & 297,0 & 3,2 & 150,1 & 1,6 & 282,6 & 3,3 & 178,8 & 4,3 \\
\hline $\begin{array}{l}\text { Chemical } \\
\text { goods }\end{array}$ & 934,0 & 8,7 & 875,0 & 9,5 & 838,3 & 9,1 & 895,5 & 10,5 & 1040,0 & 11,8 \\
\hline Prom. products & 1933,7 & 18,1 & 1778,5 & 19,4 & 2362,3 & 25,6 & 1864,2 & 22,0 & 1684,5 & 19,2 \\
\hline $\begin{array}{l}\text { Cars and } \\
\text { transport }\end{array}$ & 4173,3 & 39,0 & 3454,8 & 37,6 & 3677,5 & 39,0 & 2805,3 & 33,0 & 2979,8 & 33,4 \\
\hline Finished goods & 749,1 & 7,0 & 692,0 & 7,5 & 631,9 & 6,9 & 909,8 & 10,7 & 859,8 & 9,8 \\
\hline Others & 923,5 & 8,7 & 419,2 & 4,6 & 3022,4 & 0,0 & 1678,2 & 0,3 & 155,1 & 0,3 \\
\hline
\end{tabular}

Table 3. Diagnostics and Analysis of the Structure of Imports of the Azerbaijan Republic.

In a word, the layout of import-export goods in the republic is not entirely positive, which requires the development of the non-oil sector of the economy.

Nevertheless, the Republic of Azerbaijan is applying an import substitution policy using the possibilities of domestic production.

Diagnostics of the data obtained shows that for 2013-2017. the real market for food products increased from 2.7 million manats to 3.1 million manats.

\begin{tabular}{|l|r|r|r|r|r|}
\hline & $\mathbf{2 0 1 3}$ & $\mathbf{2 0 1 4}$ & $\mathbf{2 0 1 5}$ & $\mathbf{2 0 1 6}$ & $\mathbf{2 0 1 7}$ \\
\hline Food products & 2286,4 & 2422,0 & 2307,6 & 2964,7 & 2999,8 \\
\hline Drinks and tobacco & 231,7 & 244,8 & 224,9 & 265,4 & 302,6 \\
\hline Prom. products & 1441,8 & 1463,5 & 1375,3 & 1582,2 & 2280,8 \\
\hline Chemical goods & 200,3 & 247,2 & 353,2 & 374,2 & 513,9 \\
\hline Machinery and equipment & 262,7 & 360,9 & 304,4 & 300,0 & 280,6 \\
\hline Finished goods & 147,1 & 137,0 & 119,1 & 197,1 & 304,3 \\
\hline Total & 7244,9 & 8060,6 & 7880,4 & 8899,5 & 9723,5 \\
\hline
\end{tabular}

Table 4. The Volume of Production of the Manufacturing Industry in the Republic (million manat)

\begin{tabular}{|l|r|r|r|r|r|}
\hline & \multicolumn{1}{|c|}{$\mathbf{2 0 1 3}$} & $\mathbf{2 0 1 4}$ & \multicolumn{1}{c|}{$\mathbf{2 0 1 5}$} & \multicolumn{1}{|c|}{$\mathbf{2 0 1 6}$} & $\mathbf{2 0 1 7}$ \\
\hline Food products & 2700,6 & 2756,1 & 2593,0 & 3676,2 & 3630,8 \\
\hline Drinks and tobacco & 580,2 & 669,5 & 569,6 & 387,8 & 497,2 \\
\hline Prom. products & 3110,1 & 3023,1 & 3555,8 & 3172,7 & 3641,9 \\
\hline Chemical goods & 958,9 & 891,1 & 1001,3 & 1110,5 & 1375,2 \\
\hline Machinery and equipment & 4272,5 & 3728,5 & 3773,3 & 3002,0 & 3200,4 \\
\hline Finished goods & 746,9 & 638,9 & 661,5 & 1091,2 & 1144,8 \\
\hline
\end{tabular}

Table 5. The Real Capacity of the Commodity Market of the Republic of Azerbaijan for 2013-2017 (million manat)

According to "Table 5", the real capacity of the commodity market decreased in terms of beverages and tobacco from 580.2 million manats to 497.2 million manats, industrial goods increased from 3.1 billion manats to 3.6 billion manats, chemical products - from 958.8 million manats to 1375.2 million manats, etc. In a word, for 20132017. the volume of the capacity of the commodity market as a whole has increased (Vasilyeva O.E., 2011).

\section{Conclusions}

Research for 2013-2017 in the area of the structure of export of goods of the republic, they showed that very negative processes are observed in this area, because about $90 \%$ of exports are mineral resources and fuel, and only a small part falls on products of the commodity market;

- diagnostics and analysis of the structure of imports in the republic indicate that during the study period there is a slight decrease in the main commodity groups (with the exception of food products, chemical goods, finished goods), which indicates a partial activation of the commodity market in the country;

- calculations of the real volume of the commodity market capacity (according to the manufacturing industry data without indicators of production of energy resources and combustible minerals) in the republic increased over 2013-2017. insignificantly (food products - from 2.7 billion manats to 3.6 billion manats; beverages - from 0.6 to 
0.5 ; industrial goods - from 3.1 to 3.6 ; chemical products - from 1.0 up to 1.4 ; machinery and equipment - from 4.5 to 3.2 ; finished products - from 0.7 to 1.1 ).

\section{References}

- Lazerev N.V. Organization of innovation in construction companies. M .: buildinginformizdat. 2017.-130p.

- Strategic Road Map for the development of construction in the Republic of Azerbaijan (16.XII 2016).

- Vasilyeva O.E. Formation and economic evaluation of service support for industrial enterprise products: theory and methodology. Auto Doc. Chelyabinsk: SUSU. 2011.

- Velichko V.V. Risk management of construction projects. M: Telecom 2018-212 p.

- Virina M.E. Fundamentals of the economics of construction. M .: Academy. 2017.- 235 p.

- Zagidulina G.M. Construction Economics. M .: INFRA-M. 2015, -360 p. 